\title{
オレガノ葉のポリフェノール化合物
}

\author{
藤江歩巳，吉田久美*，大羽和子§ \\ 名古屋女子大学家政学部 \\ *名古屋大学大学院人間情報学研究科
}

\section{Antioxidative Phenolic Acids from Oregano (Origanum vulgare L.) Leaves}

\author{
Ayumi Fujie, Kumi Yoshida* and Kazuko Ôba ${ }^{\S}$ \\ Department of Food Science and Nutrition, Nagoya Women's University, 3-40, \\ Shioji-cho, Mizuho-ku, Nagoya, Aichi, 467-8610 \\ * Division of Informatics for Natural Sciences Graduate School of Human Informatics, \\ Nagoya University, Furou-cho, Chikusa-ku, Nagoya, Aichi, 464-8601
}

\begin{abstract}
We reported previously that fresh herbs belong to Labiatae, especially in oregano contained very high 1,1-diphenyl-2-picrylhydrazyl (DPPH) radical scavenging activity and polyphenol compounds. DPPH radical scavenging activity of fresh herbs was positively correlated with polyphenol content. DPPH radical scavenging activity and superoxide anion $\left(\mathrm{O}_{2}{ }^{-}\right)$scavenging activity measured by nitrite method of oregano

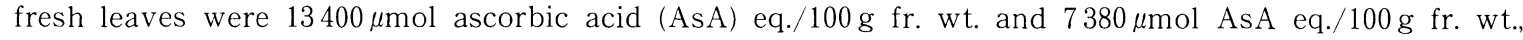
respectively. Among more than 20 peaks detected by high performance liquid chromatography (HPLC) in $80 \%$ ethanol extract of oregano leaves, rosmarinic acid, protocatechuic acid and caffeic acid were identified by retention time of HPLC and ultraviolet absorption spectrum. DPPH radical and $\mathrm{O}_{2}^{-}$scavenging activities in boiled leaves were approximately 1.3 times higher than those in fresh leaves. Although the amounts of rosmarinic acid, protocatechuic acid and caffeic acid were increased after boiling, prominently increased phenolic compound in boiled leaves was a compound of peak 1 . This was identified as 3-(3,4dihydroxy phenyl) lactic acid by ultraviolet absorption spectrum, nuclear magnetic resonance spectrum and mass spectrum. Identified 4 phenolic acids contributed approximately $55 \%$ of the DPPH radical scavenging activity and approximately $30-40 \%$ of the $\mathrm{O}_{2}{ }^{-}$scavenging activity of both of fresh and boiled leaves of oregano.

(Received Mar. 17, 2003 ; Accepted Jun. 9, 2003)
\end{abstract}

近年, 活性酸素ラジカルによる生体成分の酸化により老 化や種々の疾病が引き起こされることが明らかになってき た. 抗酸化成分を含む食品を積極的に摂取して, 活性酸素 傷害から体を守ることが健康維持や疾病予防に重要である と考えられている。 そこで, 食品に含まれる抗酸化物質に 注目が集まり，多くの抗酸化成分が食品から単離されてい $ろ^{1)}$.

ハーブは，有史以前から経験的に食物の劣化を防止する 手段に使用され，抗酸化性があることも明らかで3)，含有 される抗酸化成分についての報告あある ${ }^{3)}$ ５). 我々は， 1 , 1 -ジフェニル-2-ピクリルヒドラジル $(\mathrm{DPPH})$ ラジカル捕 捉活性を指標として多くの新鮮ハーブに活性酸素消去能が あることを明らかにした2). また， DPPH ラジカル捕捉活 性とポリフェノール量の間には正の相関性があり, DPPH

干467-8610 愛知県名古屋市瑞穂区汐路町 3-40

* 464-8601 愛知県名古屋市千種区不老町

s連絡先 (Corresponding author), koba@nagoya-wu.ac.jp
ラジカル捕捉活性は主にポリフェノール化合物に起因して いることが示唆された. シソ科のハーブには高いラジカル 捕捉活性を有するものが多く, 中でもオレガノに最も高い 活性があった，オレガノ中の抗酸化成分に関する研究は, 中谷らによっても報告されている(6)7). それらは食品中の抗 酸化成分についての報告であり, 食品の調理・加工過程に おける抗酸化成分の变化に関する報告はまだ限られてい $3^{8) 9)}$. そこで本研究では, ラジカル捕捉活性の高かったシ ソ科のオレガノに着目し，オレガノ中の抗酸化成分の同定 および加熱調理に伴うその变化を解明することを目的とし た.

\section{実 験 方 法}

\section{1. 試 料}

独立行政法人農業技術研究機構北海道農業研究センター で栽培されたオレガ/の生葉（収穫後冷却輸送, その後冷 凍保存）および現地で凍結乾燥した葉を用いた。

生葉を 10 倍量 $(\mathrm{W} / \mathrm{V})$ の冷 $80 \%$ エ夕ノール中で, ホモ 
ブレンダー（佐久間製作所製）およびガラスホモジナイ ザーを用いて，水冷しながら全試料を完全に磨砕した。磨 砕液を冷却遠心機（久保田製作所製 KR-20000 型）を用い て分離 $\left(4^{\circ} \mathrm{C}, 20000 \times \mathrm{g}, 10\right.$ 分間）した後, 得られた上清 を試料溶液とした。

加熱調理試料を調製する場合は，生葉を 10 倍量の $2 \%$ 塩化ナトリウム溶液とともに 15 分間加熱した。葉と $80 \%$ エタノール溶液が 1：10 の割合になるように，加熱濃縮し た茹で汁にエタノールを加えて $80 \%$ エタノール溶液を調 整し，上記と同様に磨砕し，加熱調理試料とした。以後， 茹で汁を含む加熱調理試料を加熱調理葉と呼ぶこととし た。

\section{DPPH ラジカル捕捉活性の測定}

DPPH（和光純薬工業製）エタノール溶液に適宜希釈し た試料溶液を同量加え， $25^{\circ} \mathrm{C}$ (暗所) で 20 分間反応させた 後, $517 \mathrm{~nm}$ の吸光度の減少を測定した ${ }^{10)}$. アスコルビン酸 （AsA）で DPPH ラジカル捕捉活性の検量線を作成し，新 鮮重 $100 \mathrm{~g}$ 当たりのラジカル捕捉活性を $\mathrm{AsA}$ 当量 ( $\mu \mathrm{mol})$ で表した。

3. スーパーオキシドアニオン $\left(\mathrm{O}_{2}^{-}\right)$捕捉活性の測定

(1) 亜硝酸法を用いた $\mathrm{O}_{2}^{-}$捕捉活性

キサンチン, キサンチンオキシダーゼ（XOD）反応系を 用い, 生成した $\mathrm{O}_{2}{ }^{-}$をヒドロキシルアミンと反応させ，そ の結果生成する亜硝酸イオンをアゾ色素に変え, $550 \mathrm{~nm}$ の吸光度を測定した ${ }^{11}$. $\mathrm{O}_{2}{ }^{-}$の生成を $50 \%$ 阻害する試料の 濃度 $\left(\mathrm{IC}_{50}\right)$ を求めた。

(2) スーパーオキシドジスムターゼ（SOD）アッセイ

キットーWST を用いた $\mathrm{O}_{2}^{-}$捕捉活性

SOD アッセイキットーWST（同仁化学研究所製）を用 いた。本法は XODの反応で生成させた $\mathrm{O}_{2}^{-}$をWST-1 と 試料中の $\mathrm{O}_{2}{ }^{-}$消去物質とで競合させる間接法である.

WST-1 ホルマザンの生成に基づく $450 \mathrm{~nm}$ の吸光度変化 はマクロプレートリーダー（日本バイオ・ラッド ラボラ トリーズ製 550 型) を用いて測定した ${ }^{12) 13)}$.

\section{4. ポリフェノール化合物の分析と同定}

(1) 高速液体クロマトグラフィ（HPLC）による分析

ポンプ：PU-980 (日本分光製), 低圧グラジェントユ ニット：LG-2080-02 (日本分光製)，検出器：UV-970 (日本
分光製）を用いて分析した。逆相カラム：Develosil ODS-

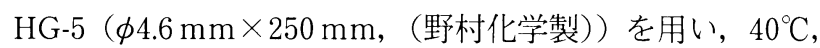
流速 $1.0 \mathrm{ml} / \mathrm{min}$ で 30 分間に A : 0.5\%トリフルオロ酢酸 を含む $10 \%$ アセトニトリルから B : 0.5\%トリフルオロ酢 酸を含む $30 \%$ アセトニトリルへのリニアグラジェント送 液を行い, $280 \mathrm{~nm}$ でポリフェノール化合物を検出した。

なお，標準物質として購入可能であったプロトカテキュ 酸, コーヒー酸, ロズマリン酸（和光純薬工業製）を用い, 既知濃度の標準物質のピーク面積からこれらのポリフェ ノールの含有量を算出した。

(2) ポリフェノール化合物の単離

オレガノ凍結乾燥葉 $6.0 \mathrm{~g}$ の $80 \%$ エ夕ノール抽出物を減 圧下濃縮後 Amberlite XAD-7 カラム $(\phi 40 \mathrm{~mm} \times 370$ $\mathrm{mm})$ にチャージし，5\%，10\%，50\%，99.5\%メタノール 水溶液で段階的に分画した。それぞれの画分を減圧下濃縮 後，ポリフェノール化合物を HPLC（分析条件は上記と同 様）で分画・分取した。

(3) 単離化合物の構造解析

$\mathrm{UV}$ 吸収スペクトル（日本分光製 V-570 型), 核磁気共鳴 スペクトル (日本電子製 JNM - A600 $\left.\left({ }^{1} \mathrm{H} 600 \mathrm{MH}_{2}\right)\right)$ ，質量 スペクトル（日本電子製 JMS-700 型）により構造解析を 行った。

\section{実験結果および考察}

\section{1. オレガノ葉の DPPH ラジカル捕捉活性および $\mathrm{O}_{2}^{-}$ 捕捉活性}

生葉および加熱調理葉の $80 \%$ エ夕ノール抽出試料の $\mathrm{DPPH}$ ラジカル捕捉活性および $\mathrm{O}_{2}{ }^{-}$捕捉活性を新鮮重 100 $\mathrm{g}$ 当たりの $\mu \mathrm{mol} \mathrm{AsA}$ 当量で示した (Table 1). DPPH ラ ジカル捕捉活性は, 生葉 $100 \mathrm{~g}$ 当たり $13400 \mu \mathrm{mol} \mathrm{AsA}$ 当

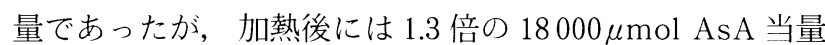
に増加した。 また，加熱後に葉之茹で汁に分けて分析した 結果, 葉に $45.7 \%$, 茹で汁に $54.3 \%$ のラジカル捕捉活性が みられた。西硝酸法で測定した $\mathrm{O}_{2}{ }^{-}$捕捉活性は，生葉 100 $\mathrm{g}$ 当たり $7380 \mu \mathrm{mol} \mathrm{AsA}$ 当量であり, 加熱後には 1.3 倍の

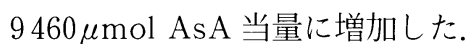

\section{2. オレガノ葉中のポリフェノール化合物}

生葉の $80 \%$ エタノール抽出物の HPLC クロマトグラム

Table 1 DPPH radical and $\mathrm{O}_{2}^{-}$scavenging activities of oregano leaves before (fresh) and after (boiled) boiling

\begin{tabular}{lcr}
\hline \hline & Fresh & Boiled \\
\hline & $(\mu \mathrm{mol} \mathrm{AsA} \mathrm{eq./100} \mathrm{g} \mathrm{fr.} \mathrm{wt.})$ \\
DPPH radical scavenging activity & $13400 \pm 300$ & $18000 \pm 700$ \\
$\mathrm{O}_{2}{ }^{-}$scavenging activity* & $7380 \pm 490$ & $9460 \pm 270$ \\
\hline
\end{tabular}

Each data value is mean $\pm S D(n=4)$.

* Nitrite method (see text) was used for assay. 
には，大小合わせて 20 以上のピークが検出された（Fig. 1). 標準物質の保持時間（RT）およびUV 吸収スペクトル と比較することにより, 最も含量の多いピーク 4 の化合物 をロズマリン酸, ピーク 2 の化合物をプロトカテキュ酸, ピーク 3 の化合物をコーヒー酸と同定した（Fig. 2).オレ

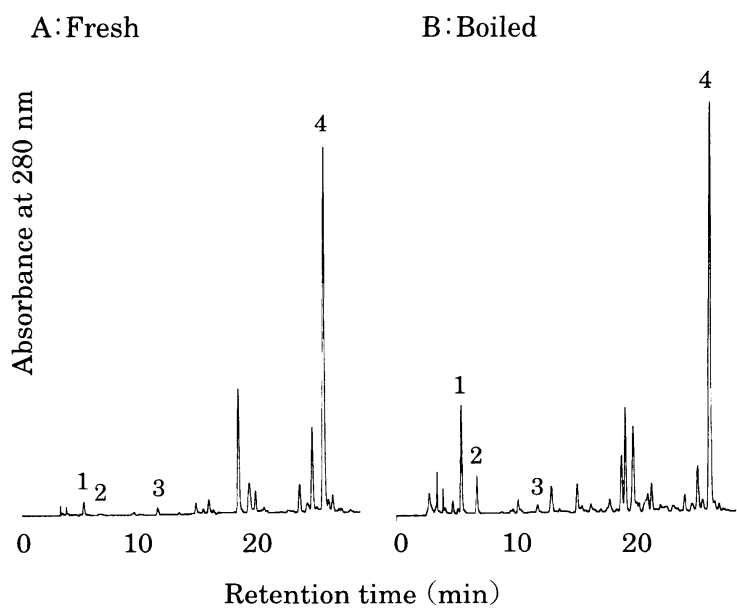

Fig. 1 HPLC chromatograms of $80 \%$ ethanol extracts from fresh (A) and boiled (B) oregano leaves

The weight of fresh leaves used for one injection was $94 \mu \mathrm{g}$, that corresponded to freeze dried leaves $25 \mu \mathrm{g}$. Boiled leaves were obtained after boiling fresh leaves in $2 \%$ sodium chloride solution for $15 \mathrm{~min}$.
ガノ葉にこれらのフェノールカルボン酸が存在すること は, 中谷らの報告 ${ }^{6) 7)}$ と一致する.

生葉と加熱調理葉の HPLC クロマトグラムを比較する と, 加熱調理後にピーク 1 が最も顕著に増大したので, 加 熱調理葉における DPPH ラジカル捕捉活性および $\mathrm{O}_{2}{ }^{-}$捕 捉活性の増大にピーク 1 の化合物が関与することが推察さ れた.

そこで，ピーク 1 の化合物を単離し構造解析を行った。 オレガノ凍結乾燥葉 $6.0 \mathrm{~g}$ から $80 \%$ エ夕ノール抽出画分と して $1.55 \mathrm{~g}$ の固形物が得られた。これを Amberlite XAD7 カラムで分画した結果, ピーク 1 の化合物は $5 \%$ タ ノール画分に溶出し, その画分の重量は $0.59 \mathrm{~g}$ であった. さらに, この画分の化合物をHPLCで分画・分取し, NMR, MS, UV, CD で構造解析を行った. その結果, 3（3，4-ジヒドロキシフェニル）乳酸であると推察された. そこで，ロズマリン酸を酸性条件下 $(3 \mathrm{~N} \mathrm{HCl} / \mathrm{MeOH})$, $95^{\circ} \mathrm{C}$ で 2 時間加熱し ${ }^{14)}$ ，ロズマリン酸の加水分解物 3-(3, 4-ジヒドロキシフェニル) 乳酸を得た。 NMR, MS, UV, CD 測定を行ったよころ，いずれも既知化合物の 3- $(3 ， 4-$ ジヒドロキシフェニル）乳酸のスペクトルと一致したこと から，ピーク 1 の化合物は 3-(3，4-ジヒドロキシフェニ ル）乳酸であると同定した（Fig. 2).

同定したポリフェノール化合物の含有量を，既知濃度の 標準物質の HPLC ピーク面積から算出し，その結果を Table 2 に示した. 3-(3，4-ジヒドロキシフェニル) 乳酸<smiles>O=C(O)C(O)Cc1ccc(O)c(O)c1</smiles><smiles>O=C(O)c1ccc(O)c(O)c1</smiles>

3- (3,4-Dihydroxyphenyl) lactic acid (peak1)

Protocatechuic acid (peak2)

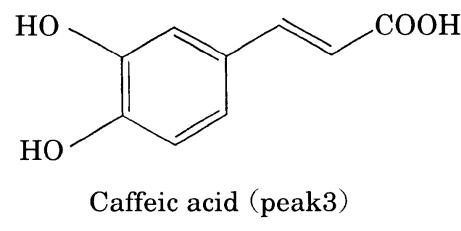<smiles>O=C(CCc1ccc(O)c(O)c1)OC(Cc1ccc(O)c(O)c1)C(=O)O</smiles>

Rosmarinic acid (peak4)

Fig. 2 Chemical structures of 4 identified phenolic acids in oregano leaves Arabic numerals in parentheses show peak number described in Fig. 1. 
Table 2 Content of phenolic acids in $80 \%$ ethanol extract of oregano leaves before (fresh) and after (boiled) boiling

\begin{tabular}{lcc}
\hline \hline & Fresh & Boiled \\
\hline & \multicolumn{2}{c}{ (mg/g fr. wt.) } \\
3-(3,4-Dihydroxy phenyl) lactic acid & $0.81 \pm 0.03$ & $4.32 \pm 0.75$ \\
& $<1.0>$ & $<5.3>$ \\
Protocatechuic acid & $0.08 \pm 0.02$ & $0.51 \pm 0.10$ \\
& $<1.0>$ & $<6.4>$ \\
Caffeic acid & $0.10 \pm 0.02$ & $0.13 \pm 0.01$ \\
& $<1.0>$ & $<1.3>$ \\
Rosmarinic acid & $6.41 \pm 0.26$ & $6.75 \pm 0.23$ \\
& $<1.0>$ & $<1.1>$ \\
\hline
\end{tabular}

Each data value is mean $\pm \mathrm{SD}(\mathrm{n}=4)$.

$<>$, Each data value in parentheses is relative value to the content of each phenolic acid in fresh leaves as 1.0.

は, 新鮮重 $1.0 \mathrm{~g}$ 当たり生葉に $0.81 \mathrm{mg}$ 存在したが, 加熱調 理葉には $4.32 \mathrm{mg}$ (生葉の含量の 5.3 倍) 存在した. プロト カテキュ酸は生葉に $0.08 \mathrm{mg}$, 加熱調理葉に $0.51 \mathrm{mg}$ （生葉 の 6.4 倍) 存在した.コーヒ一酸は生葉に $0.10 \mathrm{mg}$, 加熱調 理葉に $0.13 \mathrm{mg}$ (生葉の 1.3 倍) 存在した。ロズマリン酸は 生葉に $6.41 \mathrm{mg}$ と最も多く含有され, 加熱調理葉に 6.75 $\mathrm{mg}$ (生葉の 1.1 倍) 存在した. ロズマリン酸は, シソ科に 特異的に多く存在し，セージ17)，赤シソなどに存在するこ とが報告されている。赤シソ葉中のロズマリン酸含量は $4.65 \mathrm{mg} / \mathrm{g} \mathrm{fr} . \mathrm{wt}$. であるという報告16) あある. 本実験で測 定したオレガノ葉中のロズマリン酸含量はその 1.5 倍で あったので, オレガノ葉には赤シソ葉より高含量のロズマ リン酸が含有されると考えられる.

3. 加熱調理葉における $3-(3,4-$ ジヒドロキシフェニ ル）乳酸の増加のメカニズム

$2 \%$ 食塩水中で生葉を加熱する間に, 含有されるロズマ

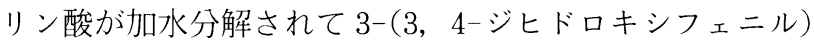
乳酸が生成するかを明らかにするために，ロズマリン酸を $2 \%$ 食塩水中で 15 分間加熱し, 加熱後の抽出物の HPLC クロマトグラムをFig. 3 に示した。 ロズマリン酸のみをこ の条件下で加熱してもピーク 1 の面積に変化は見られな かった．凍結乾燥生葉とロズマリン酸を一緒に加熱した場 合屯, 凍結乾燥生葉のみを加熱した場合とピーク 1 の面積 は变わらなかった。したがって，2\% 食塩水中で 15 分間加 熱する間にロズマリン酸が加水分解して 3-(3，4-ジヒド ロキシフェニル）乳酸が生成したのではないことが判明し た。

ロズマリン酸シンターゼ（2３．1１40) によって 3-(3, 4-ジヒドロキシフェニル）乳酸からロズマリン酸が生成さ れる経路が報告されている ${ }^{15)}$. したがって，加熱中にペク チンの可溶化がおこり, 細胞壁がルーズになり, ロズマリ ン酸の生合成の中間体としてプールされていた 3-(3，4-

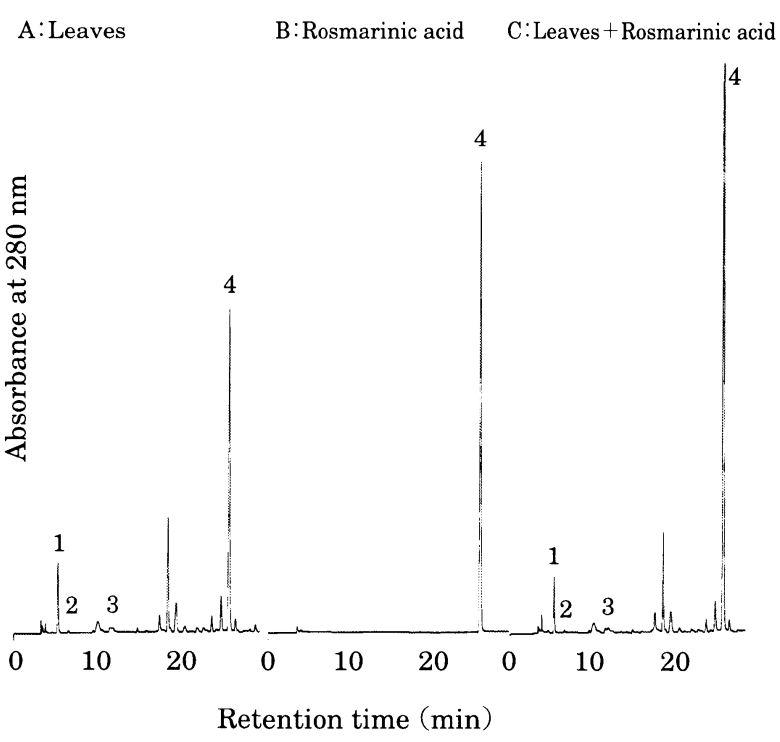

Fig. 3 HPLC chromatograms of $80 \%$ ethanol extracts from boiled leaves (A), boiled rosmarinic acid without $(B)$ and with $(C)$ oregano leaves

The weight of freeze dried leaves used for one injection was $20 \mu \mathrm{g}$. The weight of rosmarinic acid used for one injection was $1 \mu \mathrm{g}$. Boiling condition of the leaves were the same as described in Fig. 1.

ジヒドロキシフェニル）乳酸またはその配糖体などが， $80 \%$ エ夕ノール溶液中に抽出され易くなったと考えられ 万.

\section{4. 生葉および加熱調理葉の DPPH ラジカル捕捉活性} に対する 4 種のポリフェノール化合物の寄与率

本研究で同定した 4 種のポリフェノール化合物の DPPH ラジカル捕捉活性を Table 3-A に示した。 各ポリ フェノール化合物 $1.0 \mathrm{~g}$ 当たりの DPPH ラジカル捕捉活性 は，3-(3，4-ジヒドロキシフェニル) 乳酸 : $5600 \mu \mathrm{mol}$ 
AsA 当量, プロトカテキュ酸： $5000 \mu \mathrm{mol}$ AsA 当量, コーヒー酸 : $6780 \mu \mathrm{mol} \mathrm{AsA}$ 当量であった. ロズマリン酸 のラジカル捕捉活性はこれらの約 2 倍の $10600 \mu \mathrm{mol} \mathrm{AsA}$ 当量であった。

生葉および加熱調理葉の DPPH ラジカル捕捉活性を 各々 $100 \%$ とし，4種のポリフェノール化合物がそのラジ カル捕捉活性に何\%寄与するかを, 葉に存在するこれらの 化合物の含有量から算出した (Table 3-B). その結果, 生 葉のラジカル捕捉活性のうち，3-(3, 4-ジヒドロキシフェ ニル）乳酸, プロトカテキュ酸, コーヒー酸およびロズマ リン酸の寄与率は, 各々 $3.4 \%, 0.3 \%, 0.5 \%, 50.7 \%$ であっ た. 加熱調理葉のラジカル捕捉活性に対する 4 種の化合物

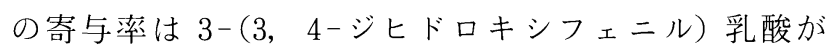
$13.4 \%$, プロトカテキュ酸 $1.3 \%$, コーヒ一酸 $0.5 \%$, ロズマ リン酸 $39.8 \%$ であった. したがって, 本研究で同定された 4 種の化合物によってオレガノ葉のラジカル捕捉活性の約 55\%が説明されたことになる.

5. 生葉および加熱調理葉の $\mathrm{O}_{2}{ }^{-}$捕捉活性に対する 4 種のポリフェノール化合物の寄与率

4 種のポリフェノール化合物の $\mathrm{O}_{2}{ }^{-}$捕捉活性を亜硝酸法
と SOD アッセイキットーWST 法の 2 つの方法で測定し た結果を Table 4-A に示した. 西硝酸法で測定したこれら の化合物の $\mathrm{IC}_{50}$ 值は，3-(3, 4-ジヒドロキシフェニル) 乳 酸 : $101 \mu \mathrm{M}$, プロトカテキュ酸 : $175 \mu \mathrm{M}$ であり,コーヒー 酸 : $40 \mu \mathrm{M}$, ロズマリン酸 : $45 \mu \mathrm{M}$ であった. SOD アッセ イキットーWST 法で測定した $\mathrm{IC}_{50}$ 值は，3-(3,4-ジヒド ロキシフェニル) 乳酸 : $37 \mu \mathrm{M}$ であったが, コーヒ一酸 : $15 \mu \mathrm{M}$, ロズマリン $: 13 \mu \mathrm{M}$ であり, 後 2 者で活性が強かっ た。亜硝酸法とSOD アッセイキットーWST 法で測定した $\mathrm{IC}_{50}$ 值は異なったが，ポリフェノール化合物間の相対的な 值はどちらの方法で測定しても類似していた.

生葉および加熱調理葉の亜硝酸法で測定した $\mathrm{O}_{2}{ }^{-}$捕捉 活性を各々 $100 \%$ とし，4種のポリフェノール化合物がそ の活性に何\%寄与するかを，葉に存在するこれらの化合物 の含有量から算出した (Table 4-B). 生葉の $\mathrm{O}_{2}{ }^{-}$捕捉活性 のうち 3-(3，4-ジヒドロキシフェニル) 乳酸, プロトカテ キュ酸, コーヒー酸およびロズマリン酸による寄与率は 各々 $2.8 \%, 0.2 \%, 0.9 \%, 27.0 \%$ であった。加熱調理葉の $\mathrm{O}_{2}{ }^{-}$捕捉活性に対する 4 種の化合物の寄与率は, 3-(3, 4ジヒドロキシフェニル) 乳酸 $11.4 \%$ ，プロトカテキュ酸

Table 3-A DPPH radical scavenging activity of 4 phenolic acids

\begin{tabular}{lc}
\hline \hline & $\begin{array}{c}\text { DPPH radical scavenging activity } \\
(\mu \mathrm{mol} \text { AsA eq. } / \mathrm{g})\end{array}$ \\
\hline 3-(3,4-Dihydroxyphenyl) lactic acid & 5600 \\
Protocatechuic acid & 5000 \\
Caffeic acid & 6780 \\
Rosmarinic acid & 10600 \\
\hline
\end{tabular}

Data values are mean value of 2 experiments.

Table 3-B DPPH radical scavenging activity of oregano leaves and contribution of 4 phenolic acids to the activity of leaves before (fresh) and after (boiled) boiling

\begin{tabular}{lcc}
\hline \hline & \multicolumn{1}{c}{$\begin{array}{c}\text { DPPH radical scavenging activity } \\
(\mu \text { mol AsA eq./100g fr. wt. })\end{array}$} \\
\cline { 2 - 3 } & Fresh & Boiled \\
\hline leaves & 13400 & 18000 \\
3-(3,4-Dihydroxyphenyl) lactic acid & $<100>$ & $<100>$ \\
Protocatechuic acid & 454 & 2420 \\
Caffeic acid & $<3.4>13.4>$ \\
& 40 & 225 \\
Rosmarinic acid & $<0.3>$ & $<1.3>$ \\
& 88 & $80.5>$ \\
& $<0.5>$ & 7160 \\
& 6790 & $<39.8>$ \\
\hline
\end{tabular}

$<>$, Each data value in parentheses is relative to fresh and boiled leaves as 100 . 
Table 4-A $\quad \mathrm{O}_{2}^{-}$scavenging activity of 4 phenolic acids

\begin{tabular}{lcc}
\hline \hline & $\mathrm{O}_{2}{ }^{-}$scavenging activity $\left(\mathrm{IC}_{50}\right)$ \\
\cline { 2 - 3 }$(\mu \mathrm{M})$
\end{tabular}

Data values are mean value of 2 experiments.

Table 4-B $\mathrm{O}_{2}^{-}$scavenging activity of oregano leaves and contribution of 4 phenolic acids to the activity of leaves before (fresh) and after (boiled) boiling

\begin{tabular}{|c|c|c|}
\hline & \multicolumn{2}{|c|}{$\begin{array}{c}\mathrm{O}_{2}{ }^{-} \text {scavenging activity }\left(\mathrm{IC}_{50}\right) \\
(\mu \mathrm{mol} \text { AsA eq. } / 100 \mathrm{~g} \text { fr. wt. })\end{array}$} \\
\hline & Fresh & Boiled \\
\hline \multirow[t]{2}{*}{ leaves } & 7380 & 9460 \\
\hline & $<100>$ & $<100>$ \\
\hline \multirow[t]{2}{*}{ 3-(3,4-Dihydroxyphenyl) lactic acid } & 203 & 1080 \\
\hline & $<2.8>$ & $<11.4>$ \\
\hline \multirow[t]{2}{*}{ Protocatechuic acid } & 15 & 94 \\
\hline & $<0.2>$ & $<1.0>$ \\
\hline \multirow[t]{2}{*}{ Caffeic acid } & 70 & 91 \\
\hline & $<0.9>$ & $<1.0>$ \\
\hline \multirow[t]{2}{*}{ Rosmarinic acid } & 1990 & 2090 \\
\hline & $<27.0>$ & $<22.1>$ \\
\hline
\end{tabular}

Data values of leaves are mean value of 4 experiments and the other data values are mean value of 2 experiments.

$<>$, Each data value in parentheses is relative to fresh and boiled leaves as 100 .

$1.0 \%$ ，コーヒー酸 $1.0 \%$ ，ロズマリン酸 $22.1 \%$ であった。し たがって，葉の $\mathrm{O}_{2}{ }^{-}$捕捉活性の 30 ～ $40 \%$ が，4 種の化合物 の $\mathrm{O}_{2}$ - 捕捉活性によって説明されたことになる.

以上の結果，オレガノ葉では，生よりも加熱調理葉の方 がポリフェノール化合物の抽出量が多くなり，抗酸化性が 高くなることが明らかになった。この結果は, Maeda ら ${ }^{18)}$ の報告と矛盾しない，健康を維持するために，「健康日本 21」では 1 日 $350 \mathrm{~g}$ 以上の野菜を摂取することを推奖して いる. 本研究結果をふまえると, 野菜類は生で食するより あ加熱調理した後, 汁と共に摂取することが好ましいとい える.

\section{要 約}

（1）オレガノ葉の DPPH ラジカル捕捉活性および巠硝 酸法で測定した $\mathrm{O}_{2}^{-}$捕捉活性は, 生葉 $100 \mathrm{~g}$ 当たり 13400 $\mu \mathrm{mol} \mathrm{AsA}$ 当量および $7380 \mu \mathrm{mol} \mathrm{AsA}$ 当量であり, 両者 とも加熱調理後に活性が 1.3 倍に増加した。

(2) オレガノ葉の主なポリフェノール化合物はロズマリ
ン酸であった，加熱調理後にロズマリン酸を始め，プロト カテキュ酸，コーヒ一酸が増大したが，中でも顕著に増大 したポリフェノール化合物を分取し，機器分析により3（3，4-ジヒドロキシフェニル）乳酸と同定した。これは， 加熱調理操作中にロズマリン酸が加水分解して生成された ものではなかった。

(3) オレガノ葉の DPPH ラジカル捕捉活性の約 $55 \%$ が, $\mathrm{O}_{2}{ }^{-}$捕捉活性の約 30〜 40\% が，本研究で同定した 4 種 のポリフェノール化合物, 3-(3, 4-ジヒドロキシフェニ ル）乳酸, プロトカテキュ酸, コーヒー酸およびロズマリ ン酸によって説明できた.

\section{文献}

1）大澤俊彦，酸化ストレス制御を中心とする食品機能因子の 化学と作用機構に関する研究，農化，76，804-813（2002）.

2）藤江歩巳，久保田真紀，梅村芳樹，大羽和子，新鮮八ーブの ビタミンC 量, DPPH ラジカル捕捉活性およびポリフェ ノール量, 調理科誌, 34，380-389 (2001).

3）吉川敏一，ハーブ，抗酸化物質のすべて，(先端医学社，東 
京), pp. 148-155 (1998).

4) 藤巻正生監修, スパイス類の抗酸化成分, 食品機能, (学会 出版センター, 東京), pp. 344-349 (1988).

5）寺沢なお子, 山崎 希, 福井優美子, ハーブ水抽出成分の抗 酸化活性，食科工，48，99-104（2001）.

6) Nakatani, N. and Kikuzaki, H., A new antioxidative glucoside isolated from oregano (Origonum vulgare L.). Agric. Biol. Chem., 51, 2727-2732 (1987).

7) Kikuzaki, H., and Nakatani, N., Structure of a new antioxidative phenolic acid from Oregano (Origonum vulgare L.). Agric. Biol. Chem., 53, 519-524 (1989).

8）高村仁知, 山口智子, 林恵理奈, 藤本さつき, 的場輝佳, 力 レーの調理過程におけるラジカル捕捉活性の変化, 家政誌, 50, 1127-1132 (1999).

9）西堀すき江, 並木和子, 野菜ジュースのスーパーオキシド アニオンラジカル消去能とその加熱処理による変化, 食科 工, 45, 144-148 (1998).

10) M.S. Blois, Antioxidant determinations by the use of a stable free radical. Nature, 181, 1199-1200 (1958).

11) Oyanagui, Y., Reevaluation of assay methods and establishment of kit for superoxide dismutase activity. Anal. Biochem., 142, 290-296 (1984).

12）浅田浩二, 中野 稔, 柿沼カッ子編, 活性酸素測定マニュア ル, (講談社, 東京), pp. 184-188（1992）。
13）受田浩之，森山洋憲，川名大介，片山泰幸，中林錦一，沢村 正義, スーパーオキシドアニオン消去活性新規測定法の食 品への応用，食科工，49，25-31（2002）。

14) Lu, Y. and Foo, L.Y., Salvianolic acid L., a potent phenolic antioxidant from Salvia offcinalis. Tetrahedron Letters, 42, 8223-8225 (2001).

15) Petersen, M.S., Characterization of rosmarinic acid synthase from cell cultures of coleus blumei. Phytochemistry, 30, 2877-2881 (1991).

16）夏目みよ゙り, 安田亜紀子, 越阪部奈緒美, 赤シソ中のロスマ リン酸含量の分析, 日本食品科学工学会第 49 回大会講演要 旨集，p. 104，名古屋（2002）。

17) Lu, Y. and Foo, L.Y., Rosmarinic acid derivatives from Salvia officinalis. Phytochemistry, 51, 91-94 (1999).

18) Maeda, H., Katsuki, T., Akaike, T. and Yasutake, R., High correlation between lipid peroxide radical and tumor-promoter effect: Suppression of tumor promotion in the Epstein-barr virus/B-lymphocyte system and scavenging of alkyl peroxide radicals by various vegetable extracts. Jpn. J. Cancer Res., 83, 923-928 (1992).

(平成 15 年 3 月 17 日受付, 平成 15 年 6 月 9 日受理) 